\title{
The Human Factor in the Development of Agriculture in Russia in Modern Conditions
}

\author{
V.V. Ilyashenko* \\ Ural State University of Economics, Yekaterinburg, Russia
}

\begin{abstract}
The article reviews the role of the human factor in the development of agriculture in modern Russia. The system of education of agricultural personnel and the specifics of workers employed in the agricultural sector are characterized. The article emphasizes the need to improve the quality of education as an integral condition for the innovative development of agriculture. There is a relatively low, in comparison with workers in other sectors of the Russian Federation, the level of wages both in the agricultural sector and in the field of training agricultural personnel. The author analyzes the influence of the monopsony nature of the labor market in the agricultural sector on the low level of wages. The data showing the insufficient financing of the sphere of training of agricultural workers are given. The measures are given, which are necessary both for the development of research work of students and for increasing the level of their professional training. The system of training scientific personnel in the agricultural sphere of activity is analyzed. The article characterizes the financial condition of agricultural organizations and its influence on solving the problems of stimulating labor in agricultural production. The author gives conclusions and proposals for the development of a system for training qualified personnel employed in the agricultural sector.
\end{abstract}

\section{Introduction}

The modern development of agricultural production in the Russian Federation is impossible without the use of highly qualified workers who are able to show innovative activity to solve professional problems. An effective and modern system of education and training of specialists for work in the agricultural sector is needed to train such personnel. To achieve this goal, it is necessary to solve a number of problems due to both the peculiarities of the agricultural sector and related to the state economic policy. This article analyzes these problems and suggests ways to solve them.

\footnotetext{
*Corresponding author: k-45409@planet-a.ru
} 


\section{Materials and methods}

When analyzing the human factor in the development of agriculture in modern conditions in Russia, scientific articles on this topic were used; statistical materials of Rosstat and other organizations. The article is written on the base of comparison methods, groupings of indicators, the index method of expert assessments, etc.

\section{Results and discussion}

The economic problems of agricultural development are largely determined by the specifics of this industry, due to the significant dependence of the products produced on natural climatic conditions, the small scale of production of a separate organization, the significant duration of the cycle of agricultural production, the specifics of the human factor in the development of agriculture.

Characterizing the human factor in the agricultural sector, first of all, it should be noted the relatively low level of education and qualifications of workers. According to the level of education in agricultural production, a significant proportion are workers with secondary general or basic general education, the proportion of which is $38.17 \%$. A significant share is also occupied by workers with primary and secondary vocational education (22.84 and $21.22 \%$, respectively) [4, p. 11].

For the period from 2000 to 2016 only a few sectors of the economy experienced a reduction in the number of employees. At the same time, the most significant decrease in the number of employees occurred in agriculture, hunting and forestry, where the average annual number of employees decreased over this period from 8996 thousand people up to 5374 thousand people, i.e. more than $40 \%$ [7, p. 226].

The number of state and municipal organizations carrying out educational activities on educational programs of primary, basic and secondary general education for the period from the beginning of the 2000-2001 to 2018-2019 in rural areas decreased from 45475 to 23494 , i.e. almost 2 times, and the number of students in educational programs of primary, basic and secondary general education during this period decreased from 6103.8 thousand people to 1895.7 thousand people, i.e. 3.2 times, which indicates a significantly reduced opportunities for the growth of human resources in agriculture [7, p. 143, 158]. Unfortunately, many of the students studying at an agricultural university are not sure about the correctness of the chosen specialty. As shown by a sociological survey conducted at the Ural State Agrarian University, if the majority of students has showed interest in their future profession, then $45 \%$ have not decided whether they need a future specialty $[10, \mathrm{p}$. 80-81]. Some authors believe that "at present, the system of staffing in the industry has been destroyed: there is a catastrophic shortage of agricultural specialists with higher education, a high staff turnover and an insufficiently effective system for their training." There is also "a large variation in the scope of training for the agrarian sector of the economy by the level of education and regions of Russia, which is often determined at present not by the regional demand, but by the objective capabilities of universities" [2].

Admission to undergraduate, specialist, and graduate programs in the enlarged group of specialties and areas of training "Agriculture and Agricultural Sciences" in 2018 amounted to $4.2 \%$ of the total admission in all specialties and areas. It should be noted that the share of workers in agriculture, hunting and forestry of the total number of employed in the economy exceeds this value $-7.5 \%[7$, p. 192, 226]. At the same time, the quality of education, the ability of a higher educational institution to form a specialist competent in 
the field of their future agricultural activities, possessing high professionalism in the context of the country's task of new industrialization and innovative development of the Russian economy, is of the first priority. We should keep in mind that the quality of education largely depends on the independent training of future specialists, "the formation of knowledge and skills of a free, critical, self-learning person who is able to solve complex (interdisciplinary and interprofessional) social, environmental and economic problems" [8, p. 8]. In accordance with the Federal Scientific and Technical Program of the Development of Agriculture for 2017-2025, "the provision of the industry with training programs for new and promising areas of training and specialties that are in demand in the labor market" are identified as important target indicators of the Program. In this regard, the task was set to "increase the level of provision of the vocational education system with educational programs in new areas of training and specialties created in the areas of program implementation" from $10 \%$ in 2020 to $100 \%$ in 2025 [11].

An obstacle for the quality training of specialists is also the insufficient financing of the activities of agricultural universities. Although agricultural universities not only train students in their chosen specialty, but also implement programs of additional vocational education and advanced training, carry out professional retraining of personnel in agriculture and other enterprises of the agro-industrial complex. As a result, the material and technical base of institutions of agricultural higher education often does not meet modern requirements. So, for example, in 2017, the Ministry of Agriculture of Russia was allocated 13.3 billion rubles for the implementation of the state assignment, i.e. less than the level of 2016 by 1.2 billion rubles, or $9.3 \%$, and even more so below the value of the total need [2]. Without modernizing the material and technical base of agricultural universities, it is impossible to solve the problem of training personnel for the innovative development of agriculture, especially since this industry is characterized by a relatively low technological level compared to industrial sectors. So, Balatsky E.V. and Ekimova N.A. believe that in conditions of a low level of the initial production base, it is impossible to implement research and development of "too high level in comparison with the existing production" [1, p.11].

A survey of 95 employers of graduates of agricultural universities from 10 regions of Russia and one of Belarus in various areas of agricultural activity showed that, according to the respondents, the least trained are workers with the specialties "scientist agronomist" (agronomy), "scientist agronomist in breeding" and " a scientist agronomist for seed production "[2]. In this regard, the proposal of N.B. Fateeva deserves attention on the legal consolidation of educational and experimental farms for agricultural universities for conducting training sessions on crop and livestock breeding, as well as for the implementation of research work of teachers and students. This will also increase the volume of practical training of students, increasing their ability to perform their functional duties after graduating from a higher educational institution.

Currently, many agricultural organizations, being the owners of fields and farms, are reluctant to provide their property for the educational process, while requiring highly qualified graduates [9].

Along with the low level of training of specialists, some authors also note the problem of "aging" of personnel, the lack of desire of graduates of agricultural universities to work in the agricultural sector, a high level of mobility of management personnel in agriculture [5]. Interest in agricultural labor and the agricultural profession should arise even at school age. In this regard, Buraeva E.V. cites the positive experience of the Tomsk region, where agricultural educational institutions in 2018 organized a course for a young agrarian, in which children aged 3 to 17 get acquainted with agricultural professions, visit fields, farms 
and processing enterprises of the agro-industrial complex, get acquainted with the basics of business, try yourself in the role of agro-startups. [2].

From the standpoint of the training of scientific personnel, it should be noted that for the period from 2000 to 2017, the number of graduate students in the Russian Federation decreased significantly from 24,828 to 10,612 , i.e., by 2.34 times. Even more significant was the reduction in the number of graduate students in agricultural sciences - from 1,047 to 381 , or 2.75 times. As a positive point, it should be noted that the proportion of postgraduate students who defended their dissertations during the preparation period in the total graduation from graduate school was the highest in agricultural sciences $-25.2 \%$ [, $\mathrm{p}$. 201.202]

According to Rosstat, the average monthly wage in agriculture for the period from 2014 to 2019 . increased from 19237 r. in 2014 up to 28257 r. in 2019, i.e. 1.47 times. At the same time, the level of wages in agriculture increased in relation to the all-Russian level of wages from 52 to $60 \%$. However, the consumer price index for the period from $2014-2019$. amounted to 1.31 . Therefore, the real wages in agriculture increased insignificantly during this period, although its approach to the all-Russian level should be assessed positively. According to a correlation-regressive study conducted by L.R. Shagivaliev, a $1 \%$ increase in wages leads to an increase in the value of the gross output of the agricultural sector of the economy by $0.86 \%[12$, p. 56]. It should be added that the level of teachers' salaries in the agricultural education system is lower than in similar educational institutions teaching students in other professions and specialties. In this regard, it is extremely difficult to attract young scientists and specialists to carry out teaching work in agricultural educational institutions.

Describing the relatively low level of wages in agriculture in theoretical terms, one should take into account the objectively monopsony nature of the labor market in agriculture. This is due to the fact that an agricultural organization in a rural settlement, as a rule, acts as the only buyer of labor. In microeconomic theory, when analyzing various models of labor markets, the features and differences of completely competitive and monopsony labor markets are characterized. In a completely competitive labor market, the optimal, most profitable level of employment, at which the gross profit of an organization hiring workers in a competitive labor market will be maximum, is achieved when the marginal profitability of labor and the wage rate, which has formed in the market for this type of labor as a whole, are equal. This situation is also optimal for the employee, since his salary corresponds to his contribution to the results of the organization's work. In a monopsony labor market, the firm exercises control over the level of wages. In a monopsony, it has the ability to set the wage rate at a level below the employee's marginal profitability. As a result, firstly, the wage rate is lower than the employee's additional contribution to the increase in the firm's gross revenue, and secondly, it is less than the wage rate that would be established in a competitive labor market [6]. According to some authors, the monopsony nature of the labor market negatively affects the prestige of labor in agriculture [3].

A specific feature of rural residents is their direct connection with nature. Therefore, observing an irrational attitude towards nature in the country, their desire to choose a profession, to abandon what they think is not prestigious agricultural specialties, with a low level of wages and social and cultural provision of rural residents, also changes to a certain extent. The low level of accessibility of social infrastructure and the possibility of obtaining social benefits in the countryside is an important reason for staff turnover. Although in the country as a whole, according to the Federal State Statistics Service, the share of the rural population for the period from 2010 to 2020 decreased slightly: from $26 \%$ to $25 \%$, respectively. If we analyze the internal Russian migration associated with the movement 
from rural to urban settlements, then in the period from 2000 to 2010, according to Rosstat, this type of migration changed insignificantly from year to year, remaining at about half a million people. However, since 2011, internal Russian migration from rural to urban settlements has increased significantly, reaching a maximum in $2013-1,013,187$ people, and in 2019 it amounted to 907,974 people.

As some authors note, $79 \%$ of domestic companies feel the need for qualified production workers [3]. The sanctions that have been imposed on Russia in recent years have necessitated the development of government programs and the allocation of additional government funds in order to support the government of agriculture and other enterprises of the agro-industrial complex, which, in turn, requires the use of additional skilled labor in these sectors of economy.

Studies have shown that the number of specialists who have worked for 3 or more years) is $89.1 \%$ in general for all agricultural specialties, including engineers $-82.1 \%$, livestock technicians $-83.3 \%$, which indicates a relatively high staff turnover. Of the total number of graduates who completed targeted training, only $19.9 \%$ were employed in agricultural organizations. [11]. Fateeva N.B. believes that only a higher educational institution is interested in the work on targeted training of students. As for municipalities and agricultural organizations, they do not show much activity in this direction [9].

It should be noted that in recent years, arrears in wages to employees of organizations in crop production, animal husbandry, hunting and the provision of related services in these areas have significantly decreased: for the period from 2015 to 2019, according to Rosstat, it decreased from 206, 0 million rubles up to 83.5 million rubles. Obviously, this was due to a certain improvement in the financial situation of agricultural organizations in recent years, which was also influenced by the economic policy of import substitution carried out in recent years. Thus, the share of profitable organizations in agriculture significantly increased: from $74.4 \%$ in 2014 to $80.4 \%$ in 2019 , and, accordingly, the share of unprofitable organizations in agricultural production decreased. The share of agricultural organizations with overdue accounts payable also decreased, from $19.6 \%$ in 2014 to $10.3 \%$ in 2019. Although the total debt on liabilities of agricultural organizations significantly increased in recent years: from 1,678.5 billion rubles in 2014 to 2,523.8 billion rubles in 2019, according to Rosstat, the debt on bank loans and loans in crop and livestock production from the end of 2014 to the end of 2018 increased by $34.2 \%$.

\section{Conclusions}

Based on the study, the following conclusions can be made:

1. To solve the problems of neo-industrial and innovative development of agriculture, a human factor of a high level of training and qualifications, capable of solving modern problems, is objectively required.

2. The modern system of all levels of education currently does not provide such a level of training for agricultural personnel. According to the level of education in agricultural production, a significant proportion are workers with secondary general or basic general education.

3. The main problems of training highly qualified personnel are: insufficient allocation of funds for the development of agrarian education, weak material, technical and practical base for training specialists. In this regard, it is necessary to increase state financial resources to strengthen the material base of institutions for training qualified specialists in agriculture and expand the basis for their practical training. 
4. Both in the system of agricultural education and in the sphere of employment of agricultural workers, there is a relatively low level of wages. To ensure further convergence of wage levels in agriculture with other sectors, government measures should be taken to increase the profitability of the agricultural sector through the use of tax incentives and preferential rates on loans.

5. To reduce the turnover of personnel and to increase staffing in agriculture, it is necessary to take both measures aimed at increasing the responsibility of employers for the targeted use of specialists and ensuring the social development of rural areas.

6. To expand the financial capabilities of agricultural organizations, continue the state economic policy of import substitution.

7. In order to train highly qualified personnel, the number of graduate students in agricultural sciences should be increased and the quality of their training should be improved.

\section{References}

1. E.V. Balackij, N.A. Ekimova, The Manager, 10(5), 9 (2019)

2. E.V. Buraeva, Bulletin of Agrarian Science, 2(77), 96 (2019)

3. V.I. Veklenko, S.P. Pugach, Bulletin of the Kursk State Agricultural Academy, 7, 51 (2017)

4. A.S. Volchyonkova, T.S. Kravchenko, Bulletin of Rural Development and Social Policy, 1(17), 8 (2018)

5. N.S. Zonova, L.A. Kozlova, Advances in modern science and education, 3(3), 152 (2017)

6. V.V. Il'yashenko, Microeconomics: A Study Guide, 218 (1999)

7. N.V. Bondarenko, D.R. Borodina, L.M. Gohberg et al., Education Indicators: 2020: A Statistical Digest, 496 (2020)

8. V.L. Tambovcev, I.A. Rozhdestvenskaya, The Manager, 11(1), 2 (2020)

9. N.B. Fateeva, Agrarian Bulletin of the Urals, 7 (149), 114 (2016)

10. N.B. Fateeva, Agrarian Bulletin of the Urals, 8 (199), 80 (2020)

11. Federal scientific and technical program for the development of agriculture for 20172025, adopted by the creation of the government of the Russian Federation on August 25, 2017

12. L.R. Shagivaliev, Bulletin of the Kursk State Agricultural Academy, 6, 56 (2017) 